\title{
UPDATED KNOWLEDGE ON FLOODS AND RISK MANAGEMENT IN THE MIDDLE EBRO RIVER: THE “ANTHROPOCENE” CONTEXT AND RIVER RESILIENCE
}

\author{
ALFREDO OLLERO ${ }^{1 *}$, J.HORACIO GARCÍA ${ }^{2}$, \\ ASKOA IBISATE ${ }^{3}$, MIGUEL SÁNCHEZ FABRE ${ }^{1}$ \\ ${ }^{1}$ Dpt. of Geography and Regional Planning, Environmental Sciences Institute, \\ University of Zaragoza, Spain. \\ 2 Dpt. of Geography, University of Santiago de Compostela, Spain. \\ ${ }^{3}$ Dpt. of Geography, Prehistory and Archaeology, University of the Basque Country UPV/EHU, Spain.
}

\begin{abstract}
The floods of 2015 and 2018 in the Middle Ebro River have led to a rethinking and updating of the forecasting and management systems. The improvements in the flow measurement systems applied in this type of extreme phenomena have led to questioning the values that were recorded in the past, officially changing the maximum flow rates of some historical floods. This has called for the need to update the knowledge/information of those recorded in the middle Ebro River, for example changing the return periods and making previous scientific studies obsolete. Updated data are applied, trying to re-characterize the floods of Ebro River since 1950, date in which the beginning of the "Anthropocene" is evident in the river management of the mainstream and its basin. At the same time, in the proposed risk management plans compliant with 2007/60/EC Directive, the structural measures are being replaced by more respectful and better adapted prevention systems for the river. The two processes interact and are essential for educating the population on risk, adopting preventive measures that are sustainable and consistent with the authentic (corrected) characteristics of the river and its floods. Thus, scientific knowledge has been consolidated as a tool to display corrected data, or, the river's updated reality, and also to make the affected inhabitants aware of the need to follow new management protocols, focused on river resilience and social strategies.
\end{abstract}

Actualización del conocimiento sobre las crecidas y la gestión del riesgo en el Ebro medio: el contexto del "Antropoceno" y la resiliencia fluvial

RESUMEN. Las crecidas de 2015 y 2018 en el curso medio del Ebro han provocado un replanteamiento y una actualización de los sistemas de predicción y de gestión. Las mejoras en los sistemas de medición de caudal aplicadas en este tipo de fenómenos extremos han llevado a poner en duda los valores que se registraban en el pasado, modificándose oficialmente los caudales máximos de algunas crecidas históricas. Esto ha implicado la necesidad de actualizar el conocimiento sobre las constatadas en el Ebro medio, cambiando por ejemplo los periodos de retorno y quedando obsoletos los estudios científicos precedentes. Se trabaja con los datos actualizados tratando de recaracterizar las crecidas del Ebro desde 1950, fecha en la que es evidente el comienzo del "Antropoceno" en la gestión fluvial del río y su cuenca. Paralelamente, en los planes de gestión del riesgo planteados en cumplimiento de la Directiva 2007/60/CE, se van sustituyendo las medidas estructurales por sistemas de prevención más respetuosos y mejor adaptados al río. Los dos procesos interactúan y son fundamentales para educar a la población en el riesgo, adoptar medidas preventivas sostenibles y acordes con las auténticas (corregidas) características del río y de sus avenidas. Así, el conocimiento científico se ha consolidado como una herramienta para mostrar los datos corregidos, 
es decir, la realidad fluvial actualizada, y también para sensibilizar a los habitantes afectados sobre la necesidad de seguir las nuevas vías de gestión, enfocadas en estrategias de resiliencia fluvial y social.

Key words: Flooding, discharge data, flood risk, global change, mitigation measures.

Palabras clave: crecidas, datos de caudal, riesgo de inundación, cambio global, medidas de mitigación.

Received: 12 July 2020

Accepted: 28 September 2020

*Corresponding author: A. Ollero, Research Group Climate, Water, Global Change and Natural Systems, Dpt. of Geography and Regional Planning, Environmental Sciences Institute, University of Zaragoza. Pedro Cerbuna, 12 , 50009 Zaragoza, Spain. E-mail: aollero@unizar.es.

\section{Introduction}

Floods are essential hydrogeomorphological processes in the functioning of the river system. At the same time, they constitute a natural risk due to the socioeconomic conditions that processes such as bank erosion and flooding can generate. Therefore, scientific knowledge of river floods is essential for focusing and addressing risk mitigation measures. In recent decades, progress has been made in replacing traditional hard defense measures with others adapted to river dynamics (De Bruijn, 2005; Batica and Goubersville, 2016). The enactment in Europe of the Flood Risk Management Directive 2007/60/EC marked a major change in trend by promoting the integration of river and social resilience. This paradigm shift in the Ebro River management has been led by the Ebro River Basin Authority (henceforth CHE), first, by the preparation of Flood Risk Management Plan (henceforth FRMP) and, secondly, the progressive application of the Ebro Resilience River restoration strategy.

The Ebro River basin $\left(85,000 \mathrm{~km}^{2}\right)$ is the largest of the Iberian Mediterranean basins. The Ebro mainstream has a total length of $930 \mathrm{~km}$ and its middle reach of $345 \mathrm{~km}$, of free meanders in a large floodplain of $3.2 \mathrm{~km}$ in average width and $6.0 \mathrm{~km}$ in maximum width (Ollero, 1992). Therefore, the Middle Ebro River constitutes a unique fluvial space in the Iberian Peninsula due to its dimensions and its significant flooding risk. This singularity and representativeness as a great peninsular river, together with its permanent problem in risk management, justifies the selection of the Middle Ebro River between Logroño and La Zaida (Fig. 1) as study area. The average flow of the Ebro River in the study reach slightly exceeds $100 \mathrm{~m}^{3} \mathrm{~s}^{-1}\left(106 \mathrm{~m}^{3} \mathrm{~s}^{-1}\right.$ at the Mendavia gauging station) between Logroño and the confluence with the Aragón River. When receiving this tributary from the western Pyrenees, it reaches $225 \mathrm{~m}^{3} \mathrm{~s}^{-1}$ in Castejón. This flow is maintained up to Zaragoza $\left(230 \mathrm{~m}^{3} \mathrm{~s}^{-1}\right)$ and increases slightly up to $236 \mathrm{~m}^{3} \mathrm{~s}^{-1}$ (Gelsa gauging station), in the last sector of this free meandering Ebro River reach.

Middle Ebro River has several sufficiently long and previously worked series of hydrological data (e.g. Ollero, 1992, 2010). However, at the end of 2019, the modification of some maximum flow values since 1996 in the different gauging stations was confirmed. The modified data series cover 23 hydrological years, from the 1996-97 hydrological year to 2018-19. Its modification was decided after the flood in April 2018 and responded to three factors: i) the finding that the flow measurements in the last two floods (2015 and 2018) were much more reliable than in all the previous ones; ii) the greater reliability of the Doppler measurement systems, which were implemented in 1996, making suspect that prior to that date the stage-discharge curve provided very large margins of error; iii) the confirmation of the malfunction of the Castejón gauging station (ID 9002) during floods, which produces a bypass of between 300 and $500 \mathrm{~m}^{3} \mathrm{~s}^{-1}$ of flow on the left bank that cannot be measured, which was well 
documented in 2015 and 2018 (Horacio et al., 2019). Consequently, the basin organization has ruled out the Castejón station for the analysis and decision-making (although it is still operating) due to lack of quality, replacing it with the Tudela station (ID 9284), which began its measurements in 2006.

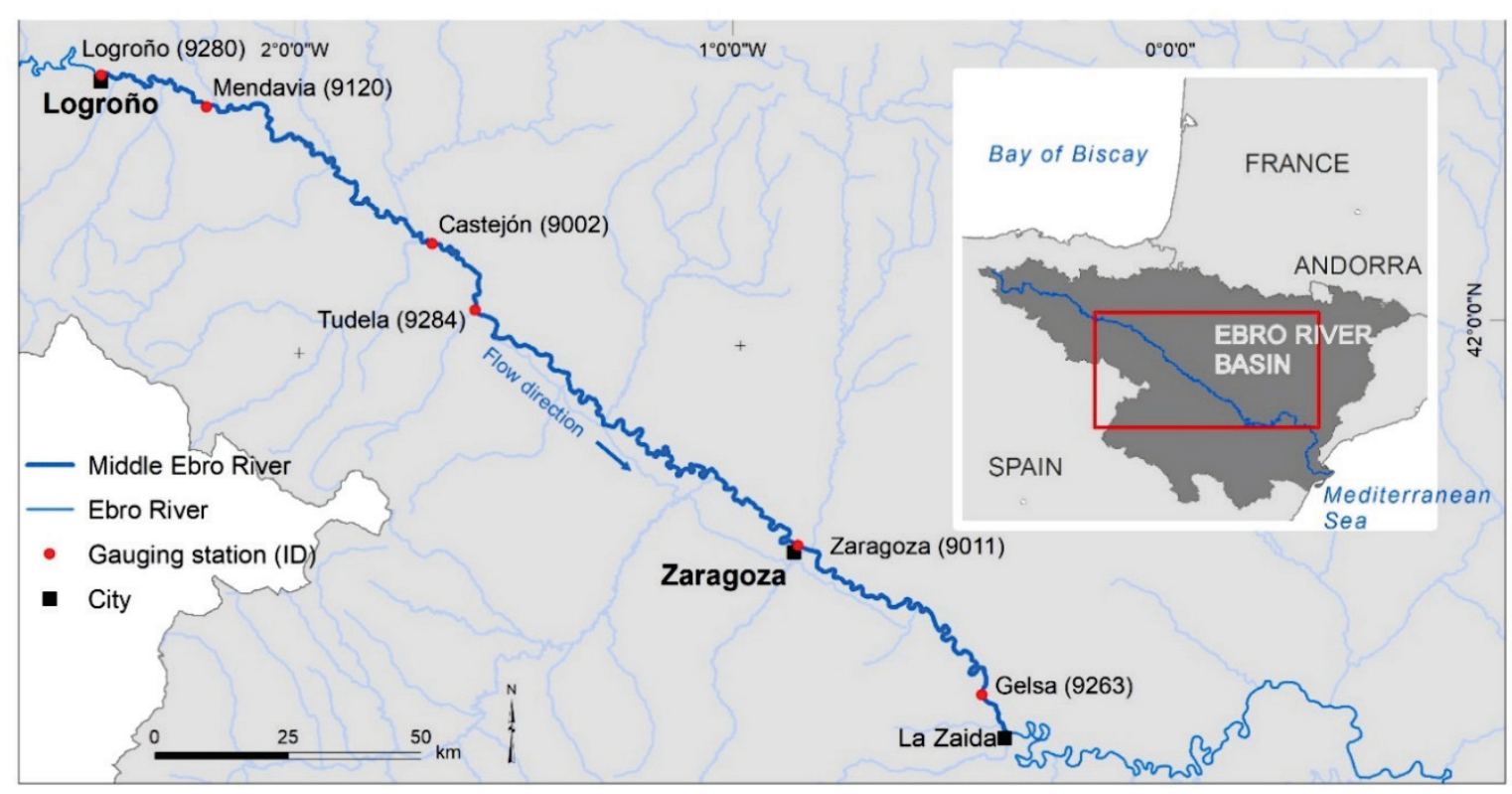

Figure 1. Location map.

The complex fluvial dynamics of the Middle Ebro River was considerably conditioned in recent decades by the global change in the basin, especially by human actions such as the regulation of flows or the defense against floods. Different researches (Ollero, 1992; Magdaleno, 2010; Ollero et al., 2015; Díaz Redondo et al., 2018) concluded that throughout the second half of the $20^{\text {th }}$ century there was a significant transformation of the fluvial functioning due to anthropic factors. It can be stated that the "Anthropocene" manifests itself in the Middle Ebro River through a great acceleration of human intervention between 1950 and 1990. Hydrological data, continuous since 1950, and aerial images, allow us to clearly verify this process (Ollero, 2010).

The objectives of this work focus on i) updating the information on the floods of the Middle Ebro River, ii) explaining its evolution based on the new data available, and iii) evaluating the changes in its management since the beginning of the "Anthropocene", 1950 (Waters et al., 2016), to nowadays.

\section{Material and methods}

Hydrological information used comes from the Information System of Flow Discharge Yearbook (source MITERD -Spanish Ministry-) and the modifications introduced by the Hydrology and River Channels Area of the CHE. The modified and already validated data have been obtained directly from the aforementioned service, as they are not yet published. The complete series since 1950 of Castejón (ID 9002) and Zaragoza (ID 9011) gauging stations, and partially those of Logroño (ID 9280), Mendavia (ID 9120), Tudela (ID 9284) and Gelsa (ID 9263) have been studied. The Tudela series has been considered to be excessively short, so the Castejón data have continued to be used for different analyses. Working with historical floods (i.e. prior to 1950) has been discarded due to the low reliability of the data and the existence of gaps in the series.

The workflow of the article is structured in two simultaneously developed stages. The first one focuses on everything related to hydrological (mainly) and sedimentological analysis, while the second one refers to interventions on the Middle Ebro River reach. 
Regarding the first stage, the hydrological events that reach the bankfull flow or overflow threshold in both Castejón and Zaragoza, or at least in one of them, have been considered as flood. The bankfull flow is a difficult parameter to identify and calculate in a channel of the dimensions and complexity of the Middle Ebro River. In the research corresponding to Ollero's doctoral thesis (1992), based on his own field observations and interviews with CHE technicians, an overflow threshold of $1800 \mathrm{~m}^{3} \mathrm{~s}^{-1}$ was established in Castejón gauging station, whereas $1600 \mathrm{~m}^{3} \mathrm{~s}^{-1}$ in Zaragoza gauging station. This value can be used for the old series (1950-1996), but it is no longer valid for the current one (since 1996 and ongoing). New field observations in recent floods and interviews with technical personnel of the CHE, as well as an unpublished research report (Martín Vide, coord., 2018), establish that this flow (series 1996-2019) should now be located at $\sim 1750 \mathrm{~m}^{3} \mathrm{~s}^{-1}$ in Castejón and $\sim 1500 \mathrm{~m}^{3} \mathrm{~s}^{-1}$ in Zaragoza.

The interpretation of the hydrological data was accomplished using a simple statistical treatment of mean and extreme values, equivalent to that performed in previous studies (Ollero, 1992, 2010; Sánchez Fabre et al., 2015, 2017). For the return periods, the Gumbel method was used, as in the same previous studies and in the internal reports of CHE.

Regarding sediment flow, the mobilization threshold was considered similar in the two gauges. The conditions of slope, cross-section and average size of the sediment are very similar, setting it at $400 \mathrm{~m}^{3} \mathrm{~s}^{-1}$ for the entire series 1950-2019.

For the second stage, the collection of the different river management actions was carried out following a double procedure. On the one hand, from personal interviews with those responsible for its execution and from documentation provided by these people, which was verified with data from the archive and communication notes from CHE. On the other hand, we worked with the most recent orthophoto (2018) from Geographic Information and Spatial Data Infrastructure of La Rioja (IDERioja), Navarra (IDENA) and Aragón (IDEAragón).

The location of the actions carried out in the Ebro River channel was mapped with the ArcGIS 10.5 software. The information was stored in a Geodatabase with three Feature classes of polygonal, linear and point geometry. This triple geometry gathers all the variability of performances. Polygonal geometry was used for the following 7 types of actions: bridge and road permeabilization, controlled flooding area, "curage", obstacle removal, relief channel, redistribution, and setback (space) -dike removal-. Lines were used for the dike removal and dike lowering performances, whereas the point only for the gate in security perimeter. The compilation, location, classification and representation of all the river management actions, as well as the identification of those already carried out and those that are in progress, has been a complex task, due to the lack of an official registry and the diversity of sources that were necessary to inquire, as already indicated.

\section{Results}

\subsection{Re-characterization and changes in the Ebro floods}

The modification of peak flow data made by CHE for the values of the new series (from the 1996-97 hydrological year and ongoing), can be seen in the changes registered for the maximum flow of each year (Table 1). In Castejón, the annual maximum instantaneous (Qci) flows have experienced increases and decreases in equal parts, while in Zaragoza the values decreased in most of the years. On average, the magnitude of the changes has meant an increase in Castejón $(+4.53 \%)$, with specific decreases of $100 \mathrm{~m}^{3} \mathrm{~s}^{-1}$ in the Qci for the 1997-98 year, compared to a decrease in Zaragoza (-3.13\%) with reductions of up to $595 \mathrm{~m}^{3} \mathrm{~s}^{-1}$ in the flood of February 2003. In this sense, the revised data confirm a greater lowering of the peak flood between Castejón and Zaragoza, especially relevant in floods such as those of February 2003 and April 2007, with laminations of $559 \mathrm{~m}^{3} \mathrm{~s}^{-1}$ and $468 \mathrm{~m}^{3} \mathrm{~s}^{-1}$, respectively. 
Table 1. Annual maximum instantaneous flow $\left(\mathrm{m}^{3} \mathrm{~s}^{-1}\right)$ in the old official series and in the new modified series at the gauging stations of Castejón and Zaragoza. Marked in red are the modifications in which the flow has been increased, in green those that have been decreased and in yellow those that have maintained the same value. In the flow lowering column the negative cases indicate that the flow rate has not been lowered, but that instead has increased between Castejón and Zaragoza.

\begin{tabular}{|c|c|c|c|c|c|c|}
\hline \multirow{2}{*}{ year } & \multicolumn{2}{|c|}{ Castejón (9002) } & \multicolumn{2}{l}{ Zaragoza (9011) } & \multicolumn{2}{c|}{$\begin{array}{c}\text { flow lowering } \\
\text { Castejón-Zaragoza }\end{array}$} \\
\cline { 2 - 7 } & old & new & old & new & old & new \\
\hline $1996-97$ & 2380 & 2380 & 2004 & 2012 & 376 & 368 \\
\hline $1997-98$ & 1475 & 1372 & 1469 & 1488 & 6 & -116 \\
\hline $1998-99$ & 791 & 791 & 845 & 828 & -54 & -37 \\
\hline $1999-00$ & 737 & 737 & 769 & 745 & -32 & -8 \\
\hline $2000-01$ & 1666 & 1566 & 1575 & 1488 & 91 & 78 \\
\hline $2001-02$ & 592 & 592 & 579 & 571 & 13 & 21 \\
\hline $2002-03$ & 2883 & 2847 & 2832 & 2237 & 51 & 610 \\
\hline $2003-04$ & 1113 & 1111 & 1145 & 1115 & -32 & -4 \\
\hline $2004-05$ & 774 & 770 & 793 & 768 & -19 & 2 \\
\hline $2005-06$ & 1575 & 1604 & 1472 & 1412 & 103 & 192 \\
\hline $2006-07$ & 2144 & 2282 & 2282 & 1952 & -138 & 330 \\
\hline $2007-08$ & 1710 & 1797 & 1567 & 1498 & 143 & 299 \\
\hline $2008-09$ & 1736 & 1797 & 1619 & 1604 & 117 & 193 \\
\hline $2009-10$ & 1935 & 2054 & 1572 & 1549 & 363 & 495 \\
\hline $2010-11$ & 1176 & 1164 & 1003 & 998 & 173 & 166 \\
\hline $2011-12$ & 676 & 740 & 623 & 623 & 53 & 117 \\
\hline $2012-13$ & 2146 & 2203 & 1755 & 1755 & 391 & 448 \\
\hline $2013-14$ & 1612 & 1527 & 1554 & 1554 & 58 & -27 \\
\hline $2014-15$ & 2691 & 2691 & 2448 & 2448 & 243 & 243 \\
\hline $2015-16$ & - & 1490 & - & 1357 & - & 133 \\
\hline $2016-17$ & - & 1606 & - & 1236 & - & 370 \\
\hline $2017-18$ & - & 2682 & - & 2037 & - & 645 \\
\hline $2018-19$ & - & 1911 & - & 1458 & - & 453 \\
\hline mean value & 1569 & 1640 & 1469 & 1423 & 100 & 217 \\
\hline & & & & & & \\
\hline
\end{tabular}

Therefore, for the analysis it is necessary to cut the available series and work separately on what happened before and after 1996. Figure 2 shows, first, how the maximum flow rates of each year were higher in Castejón and in Zaragoza in the old series 1950-1996 (henceforth series 1) than in the new series 1996-2019 (henceforth series 2). Second, there has been a decreasing trend in the old series, while in the last 23 years (series 2) the maximum flow rates of the floods have tended to increase.

Table 2 shows a detailed analysis of all the floods registered above the bankfull threshold between 1950-2019 in Castejón and Zaragoza. The values show a marked difference in the flows between series 1 and series 2 . The most significant fact is that in series 1 there are 46 episodes (i.e 1 per year on average), while in series 2, 15 are recorded (i.e. average of 0.625 per year). This trend, differentiated by series, also occurs in peak flows, 92 in series 1 (i.e. 2 per year and 2 per episode) and 32 in series 2 (1.39 per year and 2.13 per episode), as well as in the days over the movement threshold (e.g. Zaragoza: average 28 and 29 days over the movement threshold per event in series 1 and 2 respectively, while the average number of days per year over that threshold is 28 and 19 , respectively). Therefore, it can be pointed out that series 2 is characterized by less floods and less peak flows, but slightly longer and more complex than series 1 . By gauging station, Zaragoza presents more total volume, more bankfull days and more episodes over sediment flow mobilization threshold than in Castejón. 


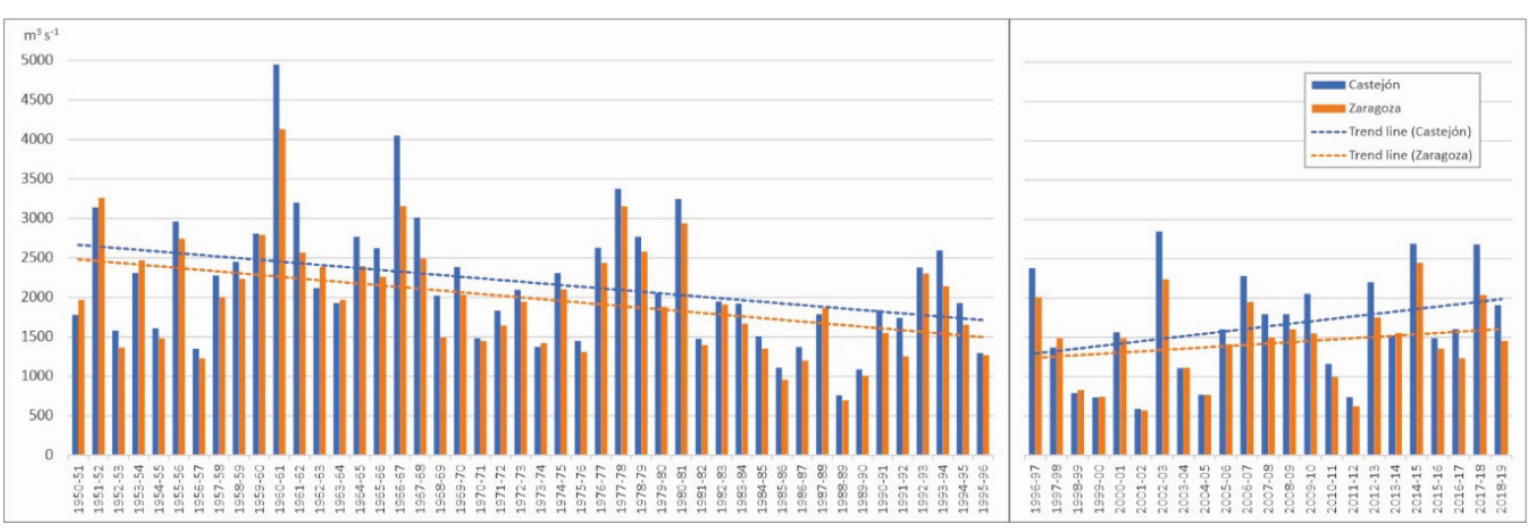

Figure 2. Annual maximum instantaneous flows $\left(\mathrm{m}^{3} \mathrm{~s}^{-1}\right)$ and trend lines in the old official series (series 1, until 1996) and in the modified one (series 2, since 1996) of the gauging of Castejón and Zaragoza.

Table 2. Data of all the floods registered above the bankfull threshold in Castejón and Zaragoza gauging stations since 1950. Those corresponding to series 2 (1996-2019) are shaded in gray.

\begin{tabular}{|c|c|c|c|c|c|c|c|c|c|c|}
\hline \multirow[b]{2}{*}{ year } & \multirow[b]{2}{*}{ month } & \multirow[b]{2}{*}{$\begin{array}{l}\text { num. } \\
\text { of peak } \\
\text { flows }\end{array}$} & \multicolumn{4}{|c|}{ Castejón } & \multicolumn{4}{|c|}{ Zaragoza } \\
\hline & & & $\begin{array}{c}\text { Qci } \\
\mathrm{m}^{3} \mathrm{~s}^{-1}\end{array}$ & $\begin{array}{c}\text { total } \\
\text { volume } \\
\mathrm{hm}^{3}\end{array}$ & $\begin{array}{c}\text { days } \\
>\text { sediment } \\
\text { mobilization } \\
\text { threshold }\end{array}$ & $\begin{array}{c}\text { days } \\
> \\
\text { bankfull } \\
\text { flow }\end{array}$ & $\begin{array}{l}\text { Qci } \\
\mathrm{m}^{3} \mathrm{~s}^{-}\end{array}$ & $\begin{array}{c}\text { total } \\
\text { volume } \\
\mathrm{hm}^{3}\end{array}$ & $\begin{array}{c}\text { days } \\
>\text { sediment } \\
\text { mobilization } \\
\text { threshold }\end{array}$ & $\begin{array}{c}\text { days } \\
> \\
\text { bankfull } \\
\text { flow }\end{array}$ \\
\hline 1951 & 03 & 3 & 1780 & 2710 & 35 & 0 & 1971 & 3032 & 40 & 2 \\
\hline 1952 & 02 & 1 & 3140 & 1040 & 9 & 3 & 3260 & 1142 & 11 & 3 \\
\hline 1952 & 04 & 1 & 2390 & 1374 & 23 & 1 & 1975 & 1231 & 19 & 1 \\
\hline 1953 & 10 & 1 & 2270 & 442 & 4 & 1 & 2000 & 542 & 6 & 1 \\
\hline 1954 & 01 & 1 & 1925 & 579 & 8 & 1 & 1780 & 841 & 12 & 1 \\
\hline 1954 & $02-03$ & 2 & 2310 & 3443 & 43 & 6 & 2470 & 3994 & 47 & 9 \\
\hline 1956 & 05 & 1 & 2960 & 701 & 9 & 1 & 2744 & 858 & 10 & 2 \\
\hline 1958 & 03 & 1 & 2280 & 1817 & 26 & 2 & 2003 & 1648 & 24 & 3 \\
\hline 1958 & 12 & 2 & 2450 & 1194 & 14 & 2 & 2237 & 1170 & 14 & 2 \\
\hline 1959 & 12 & 3 & 2810 & 4498 & 43 & 6 & 2790 & 4557 & 44 & 11 \\
\hline 1960 & $01-02-03$ & 3 & 2220 & 4847 & 78 & 5 & 2324 & 4625 & 85 & 6 \\
\hline 1960 & 10 & 1 & 2040 & 536 & 7 & 1 & 1830 & 729 & 12 & 1 \\
\hline 1960-61 & $12-01-02$ & 2 & 4950 & 7379 & 80 & 9 & 4130 & 7219 & 79 & 13 \\
\hline 1961 & $11-12$ & 3 & 3200 & 3112 & 34 & 4 & 2570 & 3310 & 36 & 8 \\
\hline 1962 & $01-02-03$ & 7 & 1850 & 5038 & 76 & 2 & 1850 & 5255 & 76 & 3 \\
\hline 1962 & 12 & 1 & 2120 & 783 & 9 & 1 & 2390 & 788 & 8 & 2 \\
\hline 1963 & 03-04 & 1 & 1365 & 937 & 15 & 0 & 1620 & 1022 & 15 & 1 \\
\hline 1963 & 12 & 1 & 1930 & 599 & 9 & 1 & 1970 & 798 & 11 & 1 \\
\hline 1964 & 12 & 1 & 1700 & 521 & 6 & 0 & 1695 & 550 & 6 & 1 \\
\hline 1965 & 01 & 1 & 2771 & 917 & 10 & 1 & 2395 & 963 & 10 & 2 \\
\hline 1965 & 12 & 2 & 2622 & 2695 & 39 & 2 & 2260 & 2114 & 31 & 2 \\
\hline 1966 & $02-03$ & 2 & 1850 & 2192 & 31 & 1 & 1611 & 2109 & 31 & 1 \\
\hline 1966 & $11-12$ & 4 & 4050 & 4107 & 47 & 4 & 3154 & 4009 & 47 & 5 \\
\hline 1967 & 11 & 1 & 2082 & 464 & 5 & 1 & 1980 & 567 & 6 & 2 \\
\hline 1967-68 & $12-01$ & 4 & 3012 & 3087 & 33 & 5 & 2494 & 2864 & 33 & 5 \\
\hline 1969 & 03 & 1 & 2024 & 1284 & 15 & 1 & 1453 & 1083 & 16 & 0 \\
\hline 1969 & 04 & 1 & 2024 & 1353 & 18 & 1 & 1495 & 1156 & 18 & 0 \\
\hline $1969-70$ & $12-01$ & 4 & 2388 & 3595 & 51 & 3 & 2031 & 4596 & 65 & 6 \\
\hline 1972 & 02 & 4 & 1832 & 2836 & 44 & 1 & 1644 & 2996 & 54 & 1 \\
\hline 1973 & 02 & 1 & 2097 & 1068 & 13 & 1 & 1946 & 1142 & 15 & 2 \\
\hline 1975 & 04 & 2 & 2309 & 2197 & 36 & 1 & 2100 & 2121 & 35 & 1 \\
\hline 1977 & 06 & 1 & 2628 & 793 & 9 & 2 & 2437 & 803 & 9 & 2 \\
\hline 1978 & 01-02-03-04-05 & 7 & 3375 & 9373 & 125 & 10 & 3154 & 8638 & 117 & 11 \\
\hline 1979 & 01-02 & 3 & 2770 & 4080 & 46 & 4 & 2581 & 3883 & 46 & 7 \\
\hline 1979 & 11 & 1 & 2056 & 820 & 10 & 1 & 1880 & 853 & 9 & 2 \\
\hline 1980 & 05 & 1 & 1912 & 411 & 6 & 1 & 1804 & 390 & 6 & 1 \\
\hline 1980 & 12 & 1 & 3250 & 1280 & 15 & 2 & 2908 & 1434 & 17 & 3 \\
\hline 1981 & 01 & 2 & 2674 & 1540 & 14 & 3 & 2940 & 1690 & 15 & 5 \\
\hline 1982 & 12 & 3 & 1950 & 1921 & 21 & 1 & 1910 & 1939 & 22 & 2 \\
\hline 1984 & 05 & 1 & 1921 & 897 & 13 & 1 & 1668 & 974 & 15 & 1 \\
\hline 1988 & 04 & 3 & 1788 & 2214 & 34 & 0 & 1869 & 2513 & 35 & 2 \\
\hline 1991 & 05 & 2 & 1837 & 1402 & 20 & 1 & 1427 & 1419 & 21 & 0 \\
\hline 1992 & 10 & 1 & 1990 & 361 & 4 & 1 & 1541 & 360 & 5 & 0 \\
\hline 1992 & 12 & 1 & 2380 & 1105 & 15 & 2 & 2301 & 1191 & 14 & 2 \\
\hline
\end{tabular}




\begin{tabular}{|c|c|c|c|c|c|c|c|c|c|c|}
\hline \multirow[b]{2}{*}{ year } & \multirow[b]{2}{*}{ month } & \multirow[b]{2}{*}{$\begin{array}{l}\text { num. } \\
\text { of peak } \\
\text { flows }\end{array}$} & \multicolumn{4}{|c|}{ Castejón } & \multicolumn{4}{|c|}{ Zaragoza } \\
\hline & & & $\begin{array}{c}\text { Qci } \\
\mathrm{m}^{3} \mathrm{~s}^{-1}\end{array}$ & $\begin{array}{c}\text { total } \\
\text { volume } \\
\mathrm{hm}^{3}\end{array}$ & $\begin{array}{c}\text { days } \\
>\text { sediment } \\
\text { mobilization } \\
\text { threshold } \\
\end{array}$ & $\begin{array}{c}\text { days } \\
> \\
\text { bankfull } \\
\text { flow } \\
\end{array}$ & $\begin{array}{l}\text { Qci } \\
\mathrm{m}^{3} \mathrm{~s}^{-}\end{array}$ & $\begin{array}{c}\text { total } \\
\text { volume } \\
\mathrm{hm}^{3}\end{array}$ & $\begin{array}{c}\text { days } \\
>\text { sediment } \\
\text { mobilization } \\
\text { threshold }\end{array}$ & $\begin{array}{c}\text { days } \\
> \\
\text { bankfull } \\
\text { flow } \\
\end{array}$ \\
\hline 1993 & 12 & 1 & 2595 & 1617 & 21 & 2 & 2140 & 1679 & 26 & 3 \\
\hline 1995 & 03 & 1 & 1930 & 859 & 13 & 1 & 1652 & 793 & 12 & 1 \\
\hline 1996 & 12 & 3 & 1769 & 1978 & 31 & 1 & 1443 & 2236 & 38 & 0 \\
\hline 1997 & 01 & 1 & 2380 & 1533 & 22 & 1 & 2012 & 1779 & 26 & 3 \\
\hline 2002 & 12 & 1 & 1887 & 841 & 11 & 1 & 1574 & 923 & 12 & 1 \\
\hline 2003 & 02 & 1 & 2847 & 1549 & 19 & 2 & 2237 & 1903 & 23 & 5 \\
\hline 2003 & 03 & 2 & 1489 & 1001 & 15 & 0 & 1806 & 1368 & 16 & 2 \\
\hline 2007 & 04 & 3 & 2282 & 2193 & 27 & 1 & 1952 & 2501 & 30 & 4 \\
\hline 2008 & 06 & 2 & 1797 & 1362 & 21 & 1 & 1498 & 1503 & 24 & 0 \\
\hline 2009 & 02 & 2 & 1797 & 2012 & 27 & 1 & 1604 & 2154 & 28 & 1 \\
\hline 2010 & 01 & 1 & 2054 & 629 & 7 & 1 & 1549 & 629 & 9 & 1 \\
\hline 2013 & 01-02-03-04 & 6 & 2203 & 7123 & 93 & 2 & 1755 & 7500 & 93 & 4 \\
\hline 2013 & 06 & 2 & 1853 & 902 & 14 & 1 & 1428 & 808 & 13 & 0 \\
\hline 2014 & 03 & 1 & 1612 & 902 & 11 & 0 & 1554 & 945 & 12 & 1 \\
\hline 2015 & $02-03-04$ & 4 & 2691 & 5411 & 63 & 5 & 2448 & 5623 & 67 & 11 \\
\hline 2018 & 04 & 1 & 2682 & 1862 & 24 & 2 & 2037 & 2005 & 24 & 5 \\
\hline 2019 & 01 & 2 & 1911 & 1569 & 21 & 1 & 1458 & 1491 & 22 & 0 \\
\hline \multicolumn{2}{|c|}{ total and mean 1950-1996 } & 92 & 2387 & 2087 & 1236 & 100 & 2182 & 2122 & 1285 & 140 \\
\hline \multicolumn{2}{|c|}{ total and mean 1996-2019 } & 32 & 2084 & 2058 & 406 & 20 & 1757 & 2225 & 437 & 38 \\
\hline \multicolumn{2}{|c|}{ total and mean 1950-2019 } & 124 & 2312 & 2080 & 1642 & 120 & 2078 & 2147 & 1722 & 178 \\
\hline
\end{tabular}

The update of the flood data in the last 23 years also implies the modification of the return periods (Table 3 and Fig. 3). Considering the total series 1950-2019, in Castejón there is no change in the values when updating the data, while in Zaragoza there is a slight decrease. The behavior by series (1 and 2) reflects a notable decrease in flows in all return periods for both stations, with a downward gradient in the percentage difference from smallest to largest magnitude. In Castejón the decreases range between 29\% (Q2) and 17\% (Q500), while in Zaragoza between 27\% (Q2) and 14\% (Q500).

Table 3. Flow rates $\left(\mathrm{m}^{3} \mathrm{~s}^{-1}\right)$ for different return periods $(t)$ obtained from the Gumbel adjustment at Castejón and Zaragoza gauging stations for the total series 1950-2019, for series 1 (1950-1996) and for series 2 (1996-2019).

\begin{tabular}{|c|c|c|c|c|c|c|c|c|c|}
\hline & & 2 years & 5 years & 10 years & 25 years & 50 years & 75 years & 100 years & 500 years \\
\hline \multirow{4}{*}{ 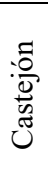 } & 1950-2019 with old data & 1875 & 2647 & 3159 & 3805 & 4284 & 4563 & 4760 & 5860 \\
\hline & 1950-2019 with new data & 1878 & 2651 & 3163 & 3809 & 4289 & 4568 & 4765 & 5866 \\
\hline & 1950-1996 (series 1) & 2062 & 2860 & 3389 & 4056 & 4551 & 4839 & 5043 & 6179 \\
\hline & $1996-2019$ (series 2) & 1474 & 2187 & 2660 & 3257 & 3699 & 3957 & 4139 & 5154 \\
\hline \multirow{4}{*}{ 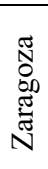 } & 1950-2019 with old data & 1707 & 2381 & 2827 & 3391 & 3809 & 4052 & 4224 & 5184 \\
\hline & 1950-2019 with new data & 1690 & 2357 & 2798 & 3356 & 3769 & 4010 & 4180 & 5129 \\
\hline & 1950-1996 (series 1) & 1880 & 2570 & 3028 & 3605 & 4034 & 4283 & 4460 & 5443 \\
\hline & 1996-2019 (series 2) & 1372 & 2012 & 2436 & 2972 & 3369 & 3600 & 3763 & 4675 \\
\hline
\end{tabular}



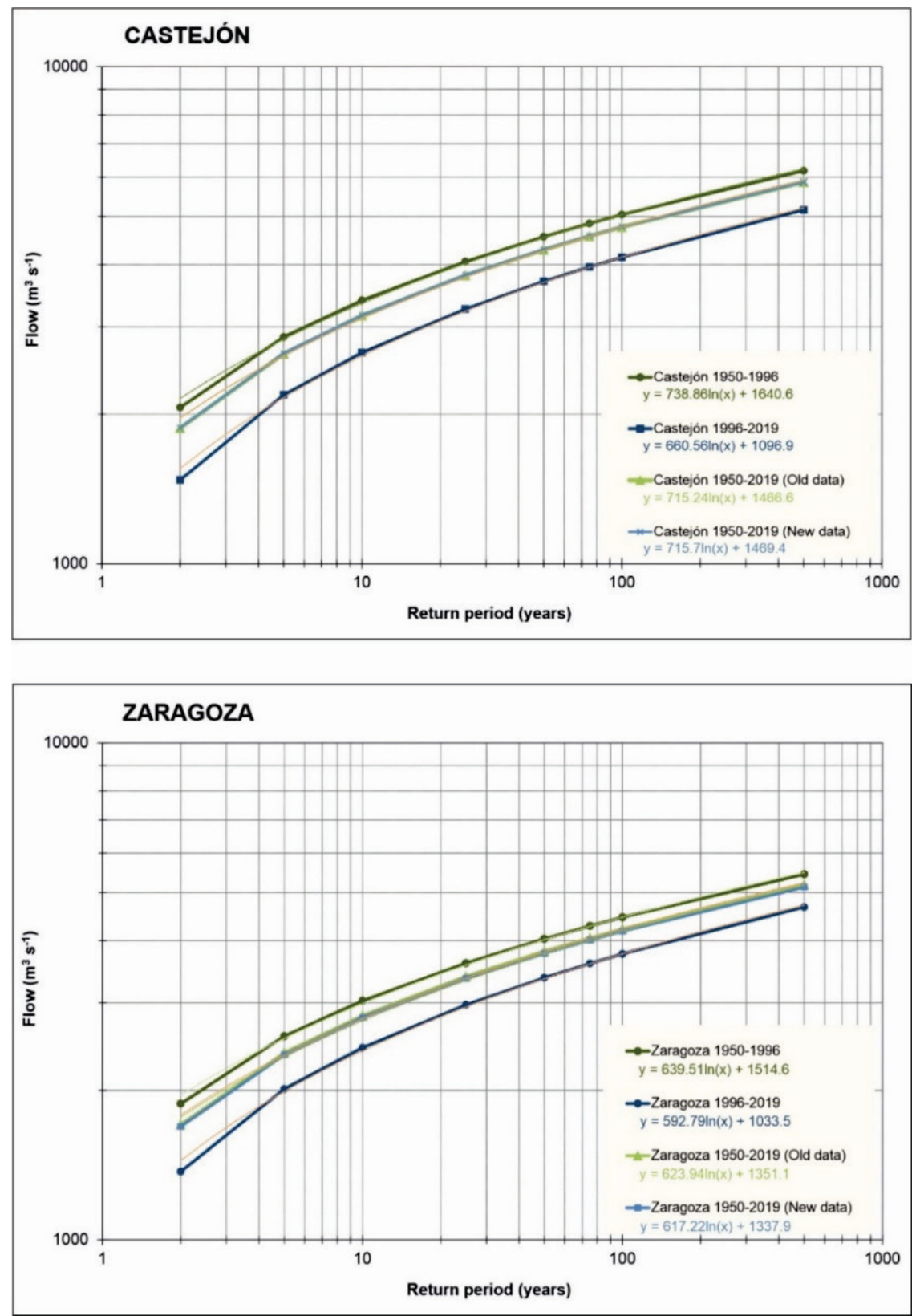

Figure 3. Equations and curves to determine the return periods.

The importance of the lack of confidence in old data is quite remarkable; as an example, the flood that marks the peak value of the series, with $4950 \mathrm{~m}^{3} \mathrm{~s}^{-1}$ in Castejón on December 31, 1960. According to series 1 , its return period would be $\sim 90$ years. If we apply the new return periods corresponding to series 2 , in which it is assumed that the flood flow is already correctly measured, the peak flow of that flood in Castejón would have been $4056 \mathrm{~m}^{3} \mathrm{~s}^{-1}$, that is, $894 \mathrm{~m}^{3} \mathrm{~s}^{-1}$ less than the measured value. In the case of the Zaragoza gauging station, a peak flow of $4130 \mathrm{~m}^{3} \mathrm{~s}^{-1}$ was recorded on that event on January 2, 1961. According to series 1, this value represented a return period of $\sim 60$ years. For this return period, series 2 indicates a peak flow of $3458 \mathrm{~m}^{3} \mathrm{~s}^{-1}$, that is, $672 \mathrm{~m}^{3} \mathrm{~s}^{-1}$ less than what was measured. These new values, "corrected" in a very simple way, of $4056 \mathrm{~m}^{3} \mathrm{~s}^{-1}$ in Castejón and $3458 \mathrm{~m}^{3} \mathrm{~s}^{-1}$ in Zaragoza, are much more consistent with the levels reached (not only with the officials of the gauging stations, but also with those of the existing markers in some settlements) and with the flood lowering level, both for the authors of this article and for the technical personnel of CHE. 
The seasonality of the floods is not a function of the quality of their measurement, so it is a parameter that can be analyzed in the whole of the 1950-2019 series for all recorded events, i.e. those that exceeded the bankfull flow in Castejón and/or in Zaragoza. However, as seen in Figure 4, series 2 floods are concentrated in winter and spring, with the same number of events in January, February, March and April, whereas those of the autumn season (October, November and early December) that happened in series 1 are completely disappeared. This phenomenon must be related to regulation, since the reservoirs have the capacity to retain the first floods that occur after the summer dry season.
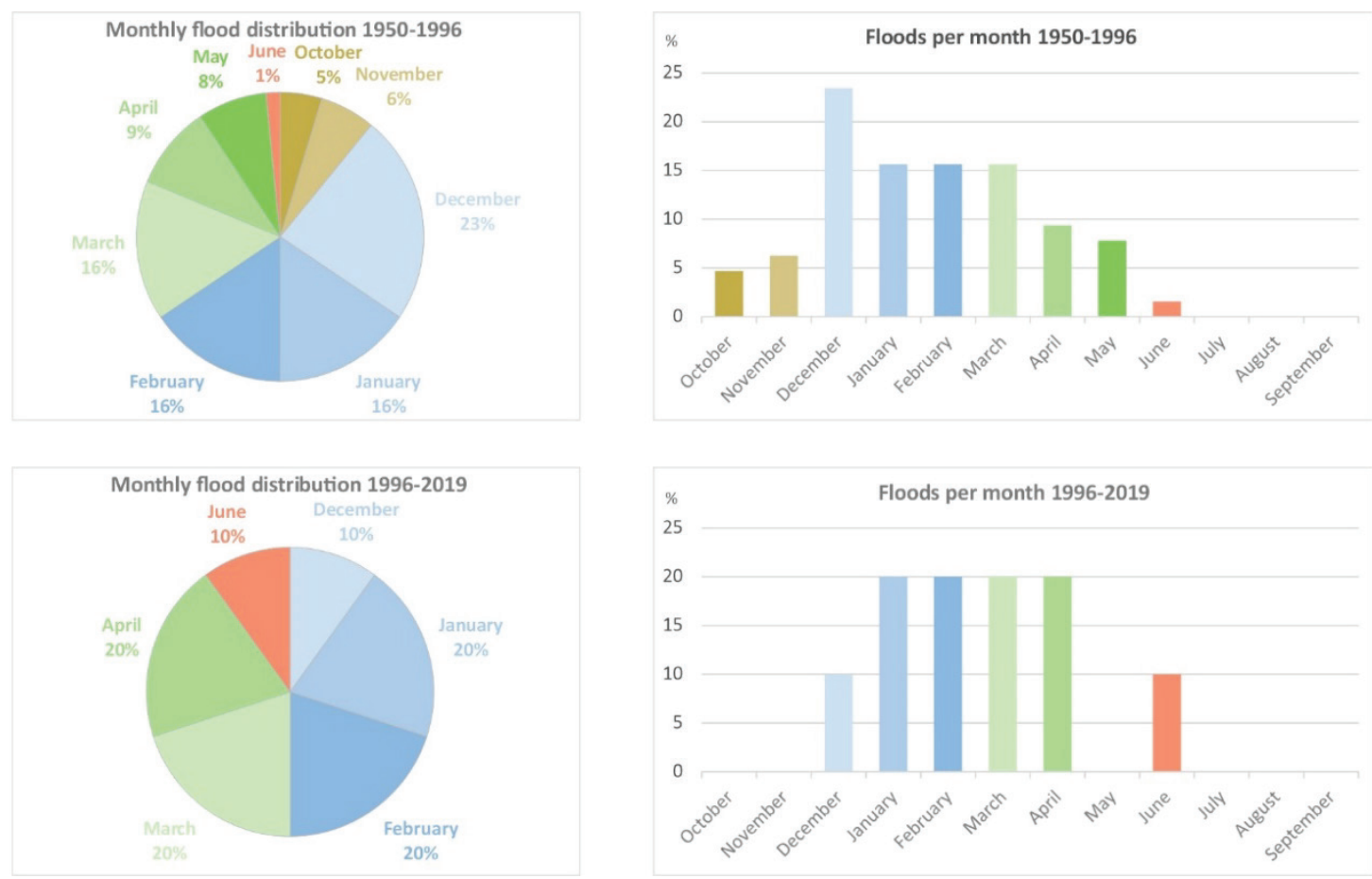

Figure 4. Monthly flood event percentage.

Another issue that can be analyzed in its evolution throughout the entire 1950-2019 series is the simple or complex nature of the events and the shape of the hydrographs (Fig. 5). A trend towards increasing, more complex floods over time seems clear, with several points ( 2 per episode in series 1 and 2.13 per episode in series 2, as already noted), and slower, with flattened hydrographs, as already found by Sánchez Fabre et al. (2015). To a large extent it seems to be due to the regulation of flows, to the increasing use of reservoirs for control and peak flow lowering in each flood. And this could lead to a new hypothesis: that the current floods are more voluminous than the old ones (about $100 \mathrm{hm}^{3}$ in Zaragoza, however, in Castejón the average volume is $30 \mathrm{hm}^{3}$ less), but their peaks are being lowered by the reservoirs. Therefore, regulation is affecting both seasonality and maximum flow values. 

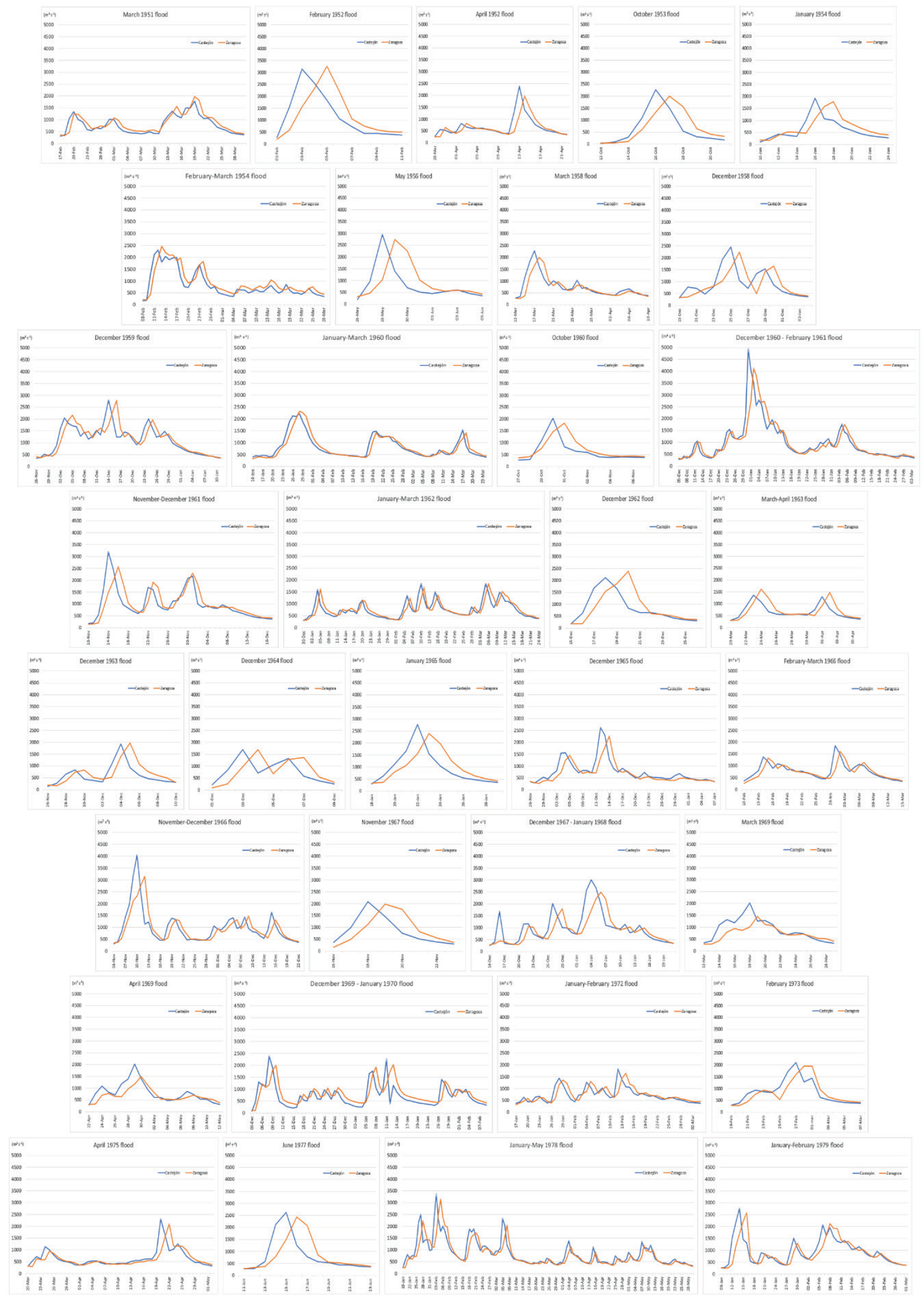

Figure 5. Hydrographs of floods since 1950. 


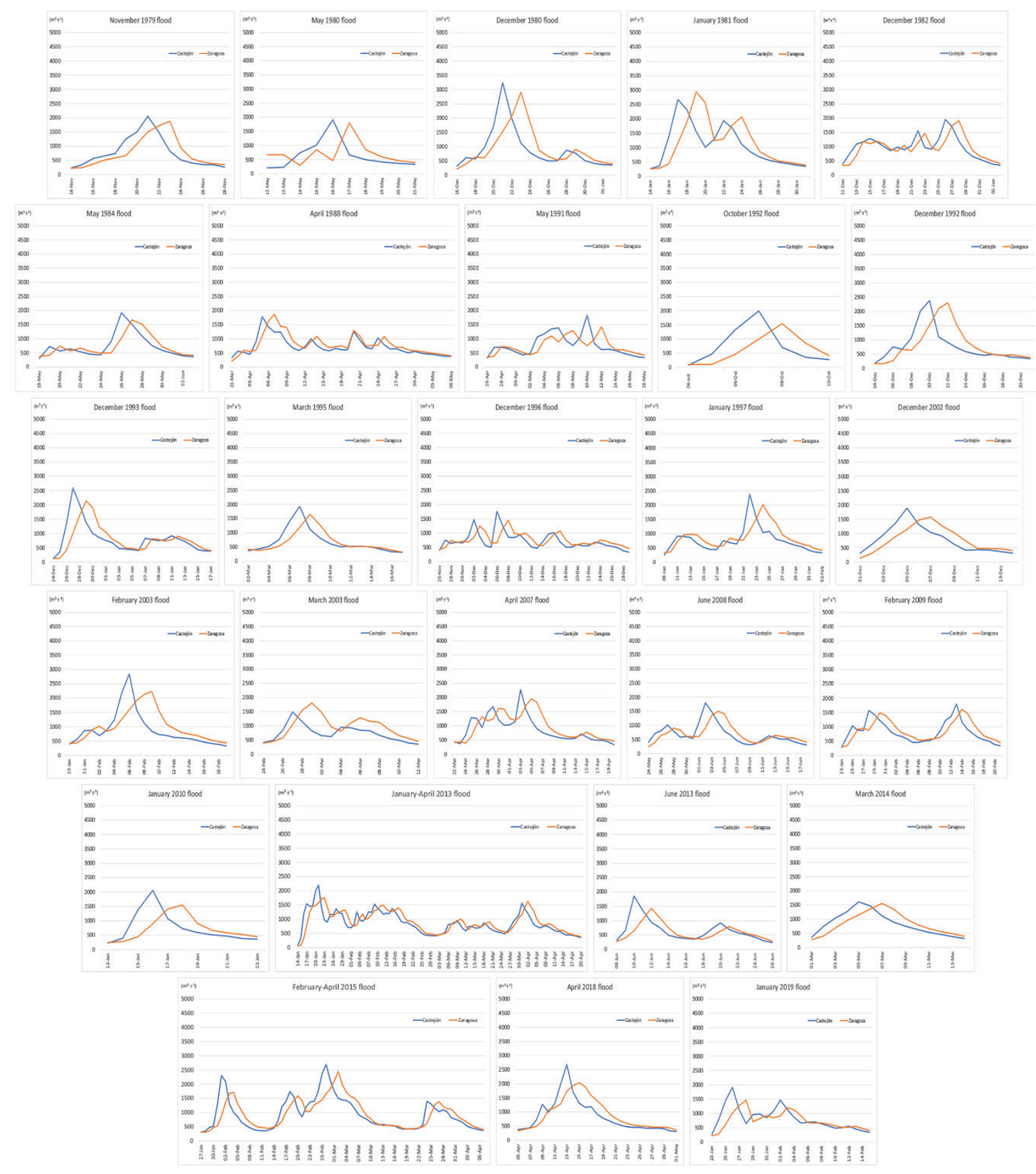

Figure 5. Hydrographs of floods since 1950 (cont.)

Figure 6 shows with second degree polynomial curves that the descending trends of maximum flows in Castejón and Zaragoza stop, approximately, from 1996, coinciding with the new period of corrected data (series 2). From this year there is a marked trend towards stability. In the case of the Mendavia gauging station, the line remains approximately horizontal throughout the entire period of time. The rest of the gauging stations maintain the same behavior as the nearby stations. This first analysis of the data seems to confirm the hypothesis, already alerted to by the Hydrology and Channels Area of CHE, that flood flows historically presented calculation deficiencies, at least until 1996, and that in general before that date, the maximum flows registered in the gauging stations of Castejón and Zaragoza were overvalued. The problem is that it is impossible to reconstruct the flood flows prior to 1996, so the evolutionary interpretation is still hypothetical. Historic floods, prior to 1950, cannot help 
either because of the unreliability of the data. To all this is added the scarcity of marks and records on the ground for the different floods. Ancient floods have been studied in as much detail as possible, the vast majority of events are well-known, and their peak flows have been estimated from models (Balasch et al., 2019), but the calculated flows cannot be integrated into the analysis with current ones due to temporary gaps and methodological differences. In any case, it does seem evident that there were great floods in the past with values much higher than those of the last century: Balasch et al. (2019) have calculated $5560 \mathrm{~m}^{3} \mathrm{~s}^{-1}$ for that of $1643,5180 \mathrm{~m}^{3} \mathrm{~s}^{-1}$ for that of $1775,4600 \mathrm{~m}^{3} \mathrm{~s}^{-1}$ for that of 1787 , $4844 \mathrm{~m}^{3} \mathrm{~s}^{-1}$ for that of 1871 and $3600 \mathrm{~m}^{3} \mathrm{~s}^{-1}$ for that of 1930 .

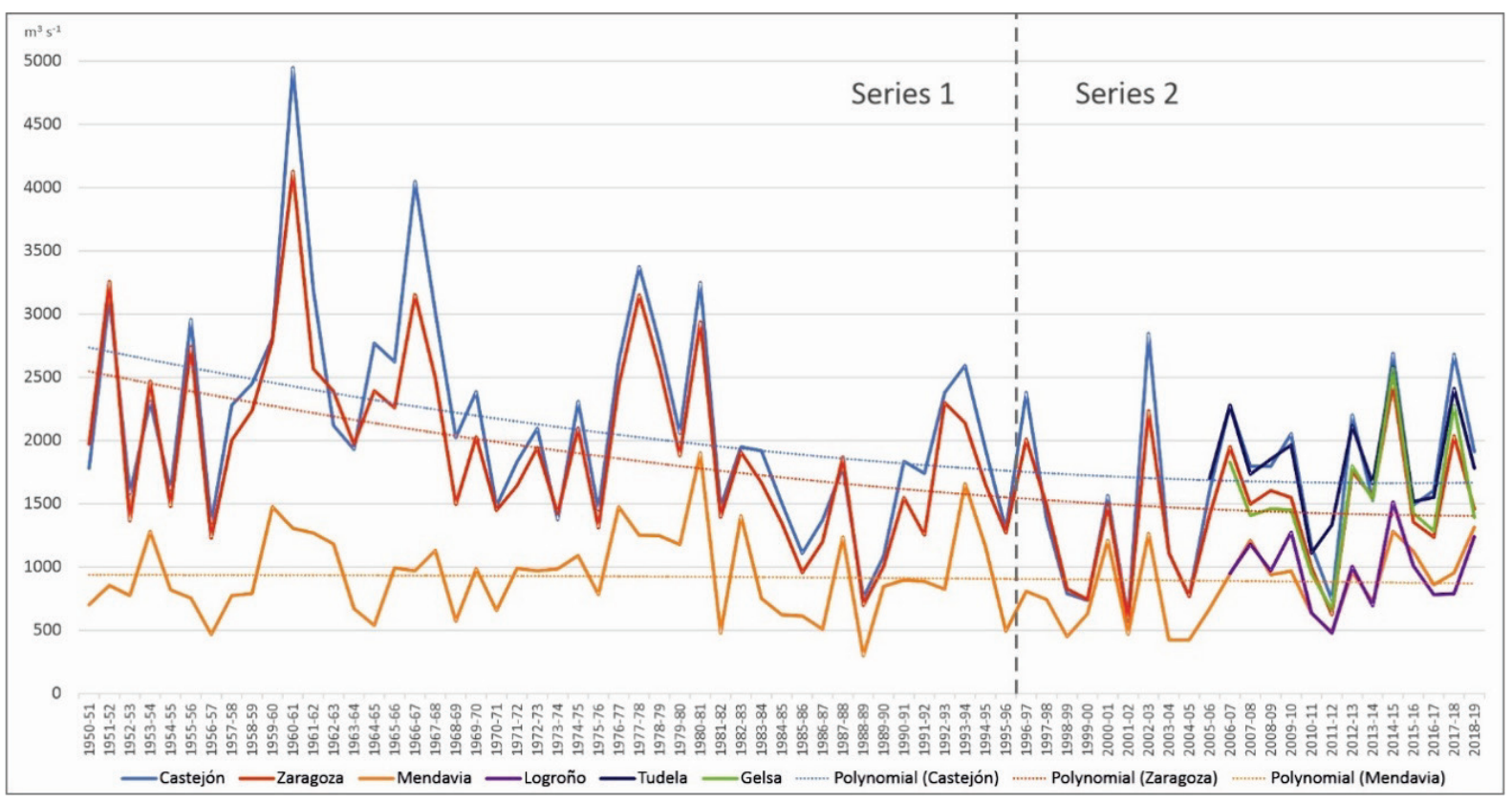

Figure 6. Evolution of annual peak flows $\left(\mathrm{m}^{3} \mathrm{~s}^{-1}\right)$ in the 6 gauging stations of the Middle Ebro River and seconddegree polynomial curves trend lines of the 3 gauging stations with complete series.

Figure 7 shows the evolution of the annual mean data adjusted with a third-degree polynomial line. A marked wet period is observed from 1950 to 1988 , the driest during the last decade of the $20^{\text {th }}$ century and first decade of the $21^{\text {st }}$ century, and the new increase in flow rates in the second decade of the $21^{\text {st }}$ century. Also highlighted is the fact, reflected in the trend lines, that in most of the years up to 1979 a higher average flow was recorded in Castejón than in Zaragoza, whereas from that date the opposite is clearly the case. This may be due to different factors, for example, variations in water consumption for agriculture (Imperial and Tauste Channels) or contributions from the tributaries (Queiles, Huecha, Arba and Jalón Rivers) that arrive between the two gauging stations. But it can also confirm that i) the flows before 1996 were not well measured, or ii) the flood flows were frequently overvalued, with the consequent repercussion on the computation of the annual average flows. Inverse behavior to that of the annual peak flows, which maintains throughout the series from 1950 to 2019, higher values in Castejón than in Zaragoza, linked to the lowering of the peak of the flood that the overflow allows. 


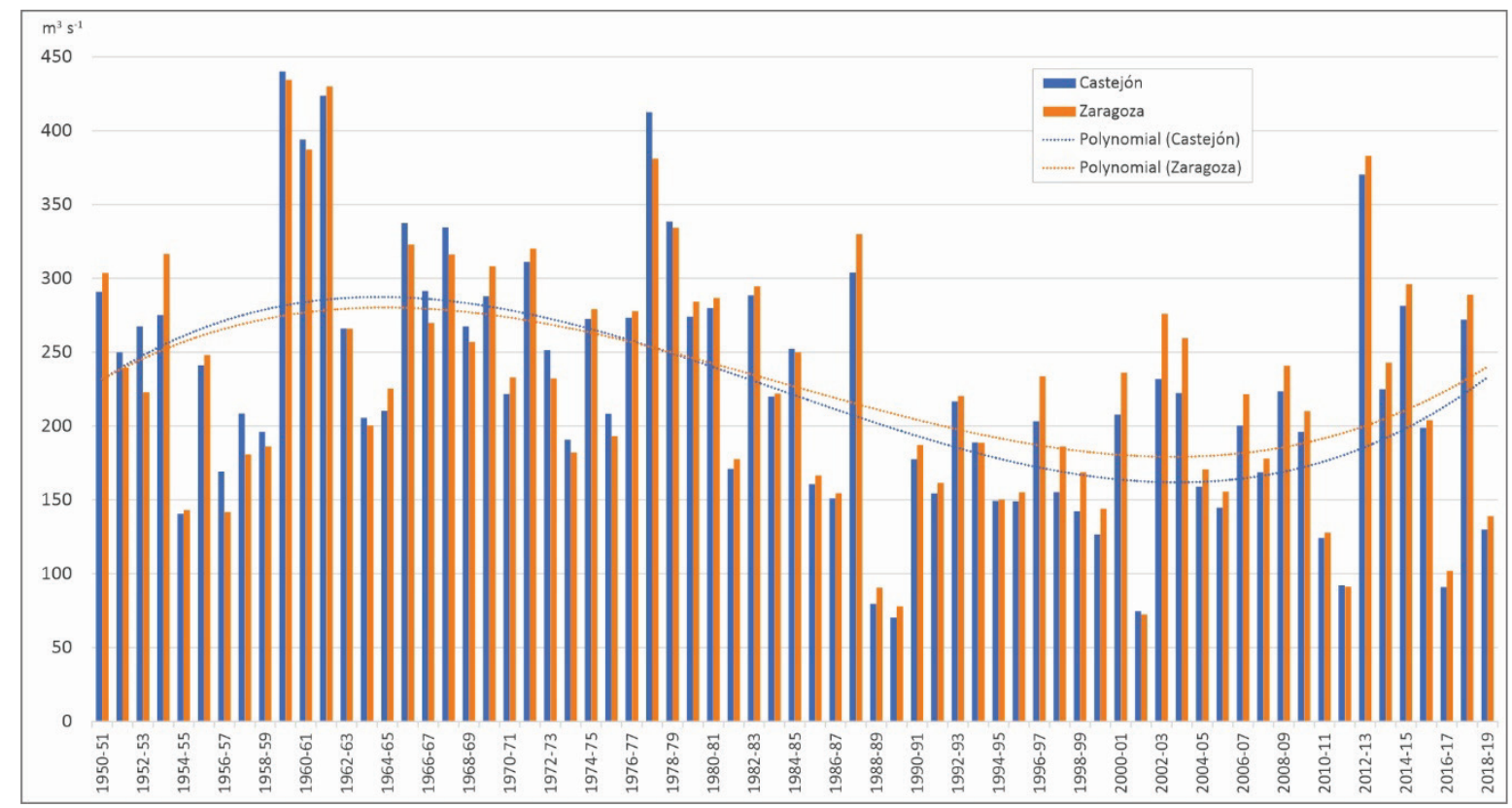

Figure 7. Evolution of annual average flows $\left(\mathrm{m}^{3} \mathrm{~s}^{-1}\right)$ since 1950 and third-degree polynomial trend lines in the gauge stations of Castejón and Zaragoza.

\subsection{Management risk evolution}

The floodplain in the Middle Ebro River constitutes a risk territory with a total area of $744 \mathrm{~km}^{2}$. Throughout history, this area of enormous fertility has been used for agricultural purposes. Most of the towns are located outside its limits, sheltered from the flood, but some also are located within the floodplain, at strategic points. Traditionally, floods caused damage, but economic and social activity was respectful and adapted and kept there because the benefits were greater (Ollero, 1992). The Middle Ebro River has two key characteristics from a danger point of view: flooding and bank erosion. Flooding is high, since floods with return periods of 10 years occupy $80 \%$ of the surface of the floodplain (Ollero, 2010). Bank erosion is very active, as demonstrated by a long history of continuous migration and meandering, as well as avulsions and river style changes between meandering and wandering both in space and in time (Ollero et al., 2017).

Risk management is therefore made up of measures to reduce damage from flooding and erosion, and has evolved throughout history. Four phases can be identified (Fig. 8):

Initial Phase. Approximately until 1945, without flow regulation and with very few bank protection actions. These began around 1900 and were local, in specific meanders to avoid erosion and with very precarious means. The Ebro River reservoir, built in the headwaters in early 1945 , marks the beginning of the regulation.

Maximum intervention phase against the river (1945-1990). It clearly marks, in the context of the Middle Ebro River, the introduction of the "Anthropocene". Regulation is extended with reservoirs, highlighting that of Yesa (1960), and a large number of bank defense works and kilometers of dikes are constructed after the great floods of 1959 and 1960-61. As a result of these works, the fear to the river is lost and the crops are moved towards the banks, gradually reducing the river space (Horacio et al., 2019) and increasing the exposure to risk. A new period of floods (June 1977, winter-spring of 1978, December 1980 and January 1981) generates significant damage and a new wave of defense actions takes place that complete the dikes, avoiding totally the dynamics of any meander (Ollero, 1992; Najes et al., 2019), considerably simplifying the channel (Ollero et al., 2015). With all this, a defense system has been created that destroys the fluvial dynamics, but it is ineffective and requires continuous maintenance, 
although the scarcity of floods between 1981 and 2003 seems to consolidate it and gives security to the riverside population, completing the vicious circle by increasing once more the agricultural and urban exposure in a flood zone (Ollero et al., 2017).

Scientific awareness phase (1990-2015). Throughout this period, the scientific community is alerted to the fragility of the management system and the destruction of the Ebro River is denounced as a dynamic meandering system, unique for its dimensions on the Iberian Peninsula. This concern is not taken seriously in society, but little by little it convinces the technical field, especially since the enactment of 2000/60/EC Directive, the preparation of the Ebro River Environmental Plan in 2005 and even more so, after the approval of 2007/60/EC Directive. However, in political decision-making, the traditional defense system still continues to be maintained and consolidated.

Current phase of shift (2015-2020). It begins with the flood of 2015 and settles with that of 2018, in which the technicians of CHE put their criteria into practice, originating from scientific awareness (until then it had not been taken into account). In this phase, the European demand of FRMPs is key, in its first preparation for 2015 and in its current second cycle until 2021. However, this moment of change has intense social opposition in the riverside towns, a belligerent standpoint by associations of "those affected by floods" that do not welcome the new management measures and intend to continue with the traditional defense system. In the process of participating in the new Ebro River Resilience strategy, this controversy is revealed. But this strategy is already a new way of acting, is proposed in the mid-term and can constitute a paradigm shift without turning back.
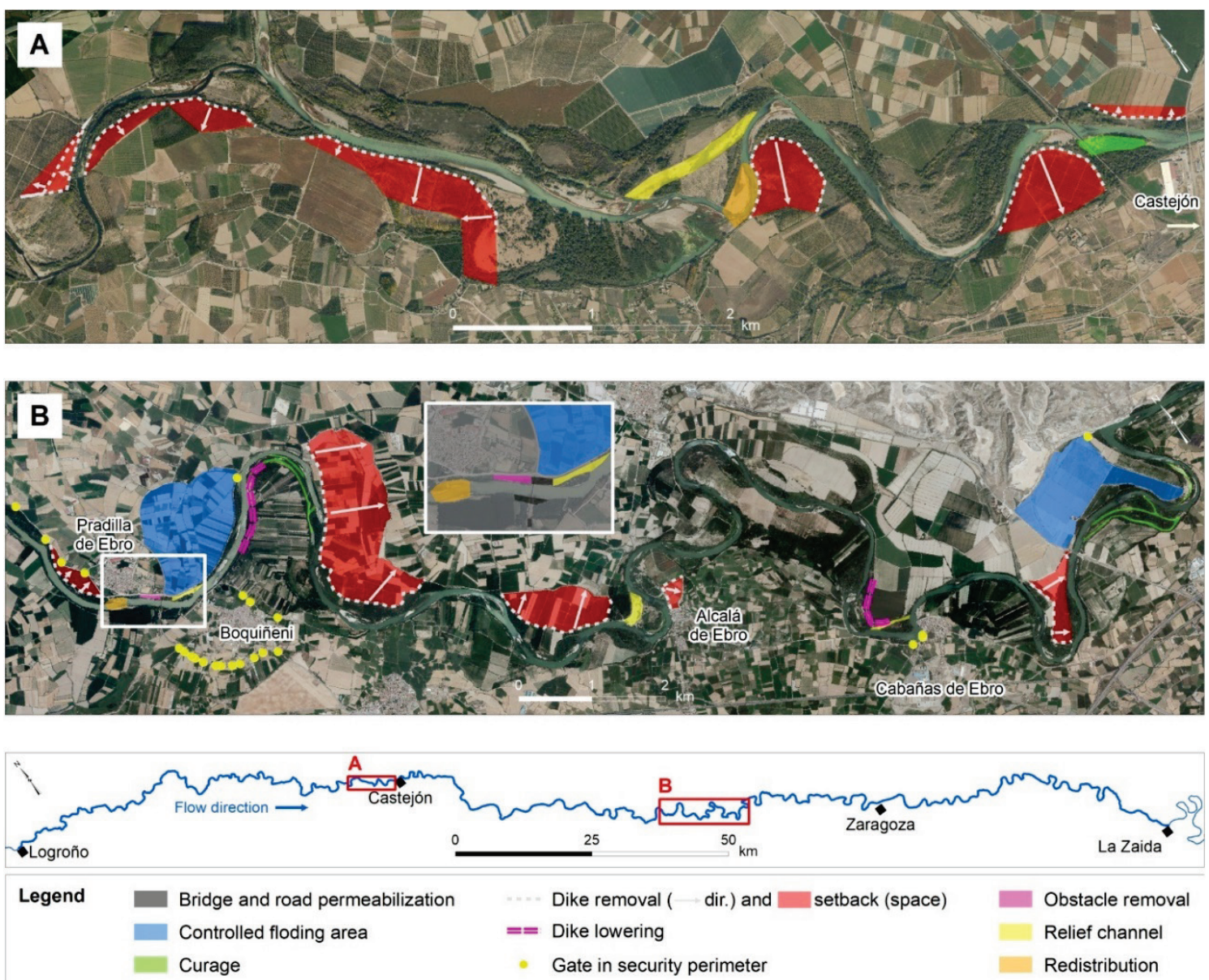

Figure 8. Actions implemented in the Alfaro-Castejón (A) and Pradilla-Cabañas (B) sectors. 
Ebro River Resilience strategy emerged in 2018 led by the competent Ministry through the CHE. The autonomous governments of La Rioja, Navarra and Aragón also participate, along with local entities in seeking the consensus of those affected people, associations and the university community. Its objective is to search for new approaches to deal with a complex problem and an inevitable natural phenomenon: prevention, protection, preparation and repair as measures to reduce the risk of flooding in the Middle Ebro River, and always in the context of the Ebro's FRMP (Gargantilla et al., 2020).

The strategy includes predictive measures, such as the improvement in the collection of hydrological data and the correction of flows that we have already analyzed, as well as educational, informative and social involvement. But the most notable are the actions that try to consolidate a new prevention and defense system based on giving more space to the river. It should be noted that the latest amendment to the Regulation of the Public Hydraulic Domain (December 2016) states that as far as possible it will tend to "increase the space (width) of the channel and not aggravate flooding and preexisting risk". In addition, it indicates that laterally to the channel raised defense works may only be built in the area of preferential flow or floodway "when they protect existing populations and public infrastructures".

The measurements carried out until May 2020 have been compiled, quantified (Table 4) and mapped (Fig. 8). Altogether they add up to 120 actions, with the removal of more than $26 \mathrm{~km}$ of linear elements and the achievement of 2,084 ha of free surface for flowing (138 ha) and for flooding (1946 ha). They respond to the following typology:

- Elimination and setback of dikes. They are longitudinal levees of compacted soil. So far, 18 cases have been acted on, reaching a total of more than 23 linear $\mathrm{km}$. The objective of their elimination is to achieve greater river space, a total of 595 ha so far, favoring overflow and reducing energy in the floodway. In most cases, a setback has been carried out, that is, the removed dike has been replaced by reinforcement as a defense for a pre-existing internal path.

- Lowering of dikes. In 4 cases so far, 3.1 linear $\mathrm{km}$ in total, this action has been chosen, which favors, to a lesser extent, the mitigation of water pressure in floods. On average, it means reducing the height of the dike from $\sim 3 \mathrm{~m}$ to $\sim 1.5 \mathrm{~m}$. It is associated with the location of floodgates and aims a controlled flooding above a level close to that of bankfull flow.

- Temporary controlled flood areas. 9 flood areas have been established so far, with a total floodable area of 1351 ha. They are associated with settlements and have a gate that connects them to the channel for filling and emptying functions. This floodgate is always located downstream of the area, so that it is flooded from its lower level, at the opposite end, in a progressive way without causing damage to the terrain. The first to be executed was that of Pradilla and, along with other associated actions, it had an excellent performance for the village in the 2018 flood.

- Relief channels. Also associated with the mitigation of damage in the vicinity of settlements. They were the first projected measures, more than a decade ago, but they were highly discussed and there were no possibilities of execution until 2015. 6 have definitely been carried out, but it is likely that they will not be carried out any more since it seems more popular to technically chose for the so-called "curages".

- "Curages". They consist in large masses of vegetated sediments permeabilised by opening branches of free circulation of flow. It increases the drainage capacity temporarily, until the river dynamics and vegetal development themselves close those branches again and requires a new intervention. Between 2018 and 2020 it was the most implemented action, with a total of 35 actions. There are more implementation projects for the coming years.

- Sediment redistribution. In 5 cases, sediment mobilization procedures have been carried out with machinery within the active channel, extracting it in one part of its section and 
accumulating in another. They seek to create a greater capacity for temporary drainage and to modify the flows to avoid the direction of the current against a settlement (e.g. the case of Pradilla).

- Security perimeters. They are a control system for overflowing waters for settlement protection. 12 have been implemented so far. Existing infrastructures (roads, highways, walls, among others) that are leveled or increased their height are used to build a security cordon that surrounds the urban area. The implementation of closing elements and gates along the perimeter is necessary, as well as markers to follow the evolution of the levels in situ and establish height/time correlations that help with decision-making (for example, in the case of an evacuation).

- Permeabilization and removal of obstacles. They are specific actions that allow drainage capacity in key places such as bridges and close to settlements. The actions carried out in the area of the Boquiñeni-Pradilla bridge or those of Pina and Novillas stand out, as well as the removal of the building of the old canoeing club in the latter village.

Table 4. Number and dimensions of implemented actions.

\begin{tabular}{|l|c|c|c|}
\hline \multicolumn{1}{|c|}{ measures } & actions & $\begin{array}{c}\text { lineal } \\
\mathrm{km}\end{array}$ & free area (ha) \\
\hline Dike removal and setback & 18 & 23.46 & 594.57 \\
\hline Dike lowering & 4 & 3.1 & \\
\hline Controlled flooding area & 9 & & 1,351 \\
\hline Relief channel & 6 & & 28.21 \\
\hline "Curage" & 35 & & 87.16 \\
\hline Sediment redistribution & 5 & & 23.39 \\
\hline Gate in security perimeter & 30 & & \\
\hline Permeabilization and obstacle removal & 13 & & \\
\hline Total & 120 & 26.56 & 2084.33 \\
\hline
\end{tabular}

\section{Discussion}

In the context of the Ebro River Basin and its main course, a process of notable population, territorial, environmental and technological changes was witnessed in the central decades of the $20^{\text {th }}$ century, which has been analyzed from very different perspectives and in different scenarios (e.g. Beguería et al., 2003; Batalla et al., 2004; Domenech et al., 2008; Cabezas et al., 2009; García Ruiz and Lana-Renault, 2011; Lorenzo et al., 2012; García Vera, 2013; López Moreno et al., 2011, 2014; García Ruiz et al., 2011, 2015; Ollero et al., 2015, 2017; Sánchez Fabre et al., 2017). In these referenced works, these changes began to be reservedly associated with the global context of consolidation of the "Anthropocene". In this article we consider that there is sufficient evidence to affirm this association. The changes observed in the basin, hydrology and the Ebro River channel are the confirmation of this new period in our environmental history. Fluvial functioning is an excellent indicator for this (Ollero, 2011).

"Anthropocene" is a term used to define human influence on Earth and its evidence in the geological record, although still without official validation and not without some controversy at its beginning, lack of geological record or relevance. The commission in charge of its definition has established a start date of 1945 (Waters et al. 2016). The 1950 milestone can be seen as the beginning of the "big acceleration" (Steffen et al., 2004) expressed by the Anthropocene Working Group since 2009 (Zalasiewicz et al., 2017). 
However, the origin of the term, and even more so the concept, is much earlier. Rull (2018) makes an analysis and compilation on the state of the matter. Not surprisingly, as early as 1873, Antonio Stoppani, in his definition of the "Anthropozoic", exemplified how engineering works have modified natural waterways and reduced or eliminated overflows, thereby altering the hydro-sedimentary operation. Others point out that the anthropic influence on natural systems is precisely what differentiates the Pleistocene from the Holocene, and that events such as changes in land use with the appearance of agriculture have already led to changes (Constante et al., 2010). Thus, the formation of the Ebro Delta has undergone an important development since Roman times linked to the modification of land uses in the basin and the increase in sedimentary contribution, a process in recession derived from a new reforestation and the construction of reservoirs (Maldonado, 1972; Guillén and Palanques, 1997). This does not prevent us from indicating that the course of the Ebro River has undergone an alteration in its operation in an accelerated way throughout the $20^{\text {th }}$ century, and especially from the middle of it with the construction of reservoirs and the defense of the banks and constriction of its channel.

In the evolution of the "Anthropocene" in the Middle Ebro River up to the present time, we have identified three phases: that of maximum intervention (1945-1990), that of scientific awareness (1990-2015) and that of the current paradigm shift (2015-2020). It is necessary to highlight some Ebro River floods that have been key in this evolution (Fig. 9).

- That of 1960-61, the largest in the $20^{\text {th }}$ century, marked the beginning of general defense actions.

- Frequent events between 1978 and 1981 caused the defense system to be completed and with it the final stabilization of the channel.

- The absence of extraordinary floods between 1981 and 2003 generated the dichotomy between two opposing perceptions: scientific awareness of the problem and the need for environmental measures in the face of the false sense of safety and the confidence of riverside society in enforced reservoir regulation mechanisms and defense.

- The flood of 2003 reactivated social concern but showed a general absence of historical memory: references had been lost. The Ebro River Environmental Plan is promoted, where the scientific field expresses its ideas, but it is not executed.

- The floods of 2007 and 2008 coincide with the start-up of the Zaragoza 2008 International Exposition, focusing concerning in urban areas (Pueyo et al., 2017). Specific initiatives to flood rural areas upstream to save the Expo were implemented, but no progress in implementing new management ideas was given, except at a scientific level.

- Once again, the floods of 2013 and 2015 broke social patterns and associations of affected people against the river authorities rewoke with great virulence, trying to avoid the start of the paradigm shift that is already evident.

- The 2018 flood definitively consolidates the decision of Ebro River Authority to change the paradigm and shows again the disagreement of those affected. 


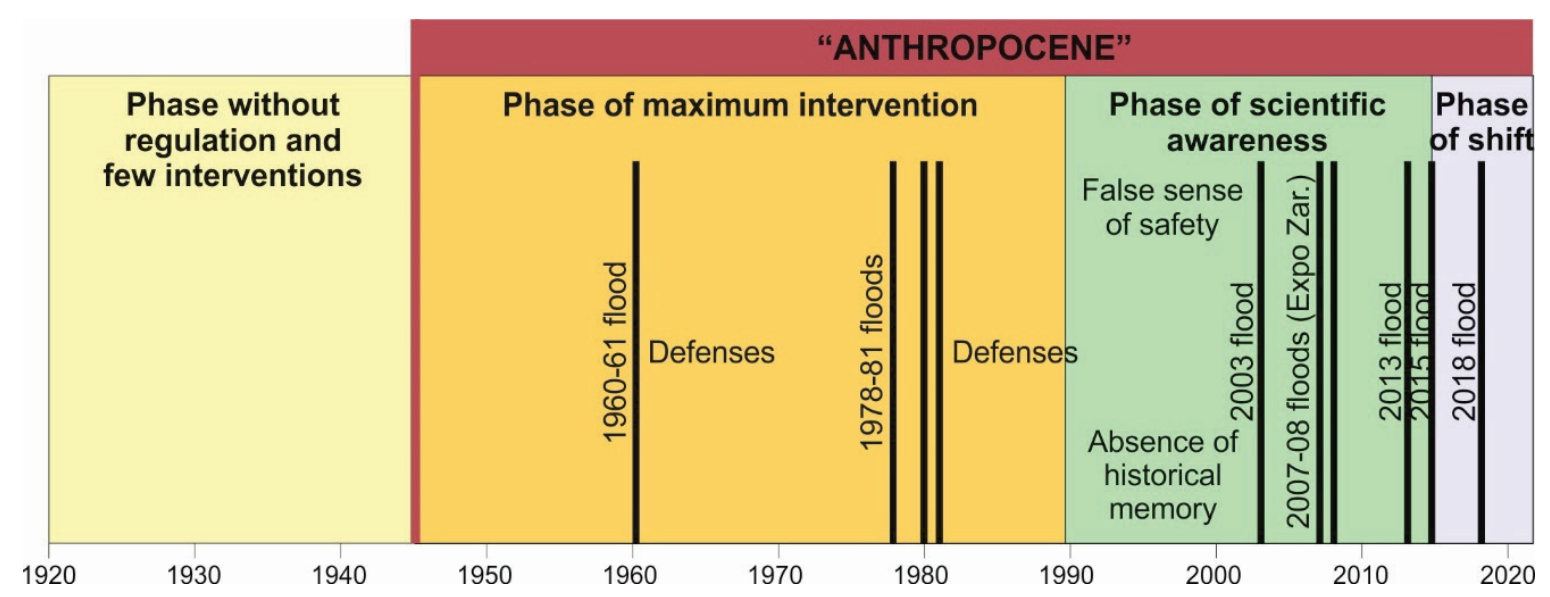

Figure 9. Evolution of risk management and perception in the last century and main floods in the last 70 years.

In this context of change, it is necessary to periodically establish moments of scientific and technical reflection and evaluation, objectives that the present work pursues. This evaluation and monitoring are important for risk management that must always be adaptive, modifying it based on the changes observed and the results obtained in previous phases, marking a permanent learning process of the river's behavior (Klijn et al., 2015). In this sense, the current change has been advocated based on the failures detected in the previous management systems. But there is another very relevant aspect: it is essential to well know the floods and to have reliable hydrological data, as measures can be built on that basis, can be properly evaluated and, in short, decisions can be taken. Hence the importance of old maximum flows having been revised and that in these new flows we can reflect and better understand the hydrological functioning of the Middle Ebro River.

It is evident, and recognized by those in charge of data collection, that the quality of the Ebro River flow records in a flood presented significant deficiencies and error margins that have only been partially corrected (and since 1996). Therefore, a longer series from that year is necessary to achieve a better knowledge of the Ebro River floods, but, for the moment, a first necessary action was, based on the corrected data, the re-characterization that has been done in this study.

Systematic hydrological measurement in floods still has limitations. The margins of error have not been evaluated at a scientific level: it is modeled for channels without gauging stations, but the data recorded in conventional stations are generally considered to be good. But it seems that the margins of error were remarkable in the past and are decreasing with new techniques. A river of the Ebro's relevance as a great peninsular river, with numerous gauging stations and very long record series, should be a model for data collection. For this reason, the present revision and others that could be carried out in the future should be published, as well as carrying out similar revisions in other river courses.

On the other hand, we are still far from being able to state to what extent the hydrological changes observed in the last 70 years are due to natural or anthropogenic factors, global change or the effects of flow management, and to what extent they are responsible for hydrogeomorphological changes in the channel. The present investigation advances along these lines, but it is a first approximation and cannot reach definitive conclusions. There is a need for a more robust procedure that we will have to implement in future work.

As already indicated, these progressive advances in hydrological knowledge should be taken into account in the adaptive management of flood and erosion risks (Woodward et al., 2014), a management whose objective must be social resilience (effective measures) and also ecological (adequate and sustainable measures). First, prediction and emergence are critical and improve as hydrological knowledge increases, and peak flows are adjusted. Second, prevention must take into 
account hydrological and geomorphological characteristics and be made up of nature-based measures (Van Wesenbeeck et al., 2017). Thirdly, a key aspect of prevention and for social resilience is education of the population, preservation of memory and experience, and awareness of new management paradigms and the adaptive nature of a process that must be continuous over time (Hillman, 2009; Waylen et al., 2018). Along these three lines, our work team advises the CHE within the framework of the Ebro River Resilience strategy.

The Ebro River Resilience strategy can be considered pioneering and original in Spain and is associated with the NWRM (Natural Water Retention Measures) that are promoted at a European level. It is an open strategy, considers the measures it is applying to be experimental, is focused as a learning process, evaluation and monitoring are continuous, responding, therefore, to adaptive management. The concept of resilience is appropriate and is approached from a river and socially integrated perspective (Parsons and Thoms, 2018). However, more ambitious steps are possible, that may perhaps come in the future, such as being able to achieve an authentic fluvial territory in the Middle Ebro River in which the river can flow with greater freedom and recover its erosion processes and, even, meander cutting. In short, to go beyond the flood space that is now being achieved.

It is necessary to evaluate the 120 measures or actions implemented so far, from the aforementioned perspective of learning and adaptive management. Dike removal is the most appropriate and effective measure to provide flood space to the river. It is an action clearly to be expanded in the future, constituting the basis of the new risk management. Temporary controlled flood areas have been very effective in the most recent floods and also have several expansion projects. These measures are concentrated in the vicinity of the settlements of greatest risk, but they will extend throughout the middle course. This is important, because a widespread system of flooding areas is required and only then will the objectives be achieved. The relief channels have shown less efficiency and maintenance is needed, so it is probable that they will not be executed any more. "Curage" is currently the most applied action, since in short, they are small channels of relief that have come to replace the big ones. But it is also a controversial measure as it eliminates natural vegetation. In some cases, it has been rejected or required to only be applied in well-identified flood channels. It is the action that requires more analysis and monitoring.

\section{Conclusions}

In this current research, the new maximum flow data modified in 2019 by CHE have been applied for the first time. This application has meant a necessary update of the knowledge on the hydrological functioning of the Middle Ebro River. In this new characterization of the floods, on a general level, the changes are not significant, but in detail, some significant and interesting aspects are observed. First, the data change of date (1996) also marks a break in the characteristics of the series, which had higher values and a decreasing trend until 1996, to change to a slightly increasing trend since 1996. Second, there are variations in the frequency of events: up to 1996 there were more floods (1 per year on average) than since 1996 ( 0.65 per year). However, the number of flow points is 2 per event until 1996 and increases to 2.13 in series 2 . In this second series, the floods are a little longer and more complex. In Zaragoza gauging station floods presented in 1996-2019 more total volume, more bankfull days and more episodes above the flow rate of sediment mobilization. Regarding seasonality, current floods are concentrated in winter and spring, with the autumn ones having disappeared. Lastly, the correction of data and the extension of the series have meant an update of the return periods, reducing the expected flow for the reference periods.

In any case, the average or most common flood in the Middle Ebro River, according to the new series 2 (1996-2019) and in Zaragoza (maximum reliability gauging station), would occur in February, has two peaks, reaches about $1800 \mathrm{~m}^{3} \mathrm{~s}^{-1}$, lowered about $300 \mathrm{~m}^{3} \mathrm{~s}^{-1}$ its peak flow due to overflows 
occurring from the confluence of the Aragón River, exceeds the bankfull level during 40 hours and the threshold of sediment mobilization lasts 19 days, and moves $2225 \mathrm{hm}^{3}$ of water in total.

Consequently, the danger remains fairly stable, but the duration of each flood has increased, as well as the transit time. Damage may be greater due to the longer duration of the flood. This is one of the arguments for implementing new management measures, highlighting the increase of on-site storage capacity.

In the recent evolution of the Middle Ebro River, a correlation between some extreme events and the social and management response has been observed, so that in integrating the main floods registered with the procedures and measures carried out, 4 phases have been identified: i) until 1945 without regulation and with few bank protection actions, ii) maximum action against the river (19451990), iii) scientific awareness (1990-2015), iv) current phase of change (2015-2020) with the implementation of FRMP and the Ebro River Resilience strategy. The measures of this implementation stand out for following the paradigm of giving more space to the river, and increasing the lowering capacity of floods in the river section itself.

In this context, the present work marks a starting or turning point laying the foundations i) towards new analyses that will have to be developed when the reviewed hydrological series are prolonged in time, ii) towards the follow-up and adaptive evaluation of the new risk management measures that are being implemented, so that they are sustainable and achieve river resilience, and iii) greater knowledge of floods and risk, which must be conveyed to the population so that it increases its memory, awareness and with it, their resilience.

\section{Acknowledgments}

The authors wish to show their sincerest gratitude to María Luisa Moreno, René Gómez, Ramón Sánchez and José Ángel Losada (CHE - Ebro River Basin Authority). This study is integrated within project CGL2017-83866-C3-1-R, financed by the Ministry of Economy and Competitiveness (Spain).

\section{References}

Balasch, J.C., Pino, D., Ruiz Bellet, J.L., Tuset, J., Barriendos, M., Castelltort, X., Peña, J.C. 2019. The extreme floods in the Ebro River basin since 1600 CE. Science of the Total Environment 646, 645-660. https://doi.org/10.1016/j.scitotenv.2018.07.325

Batalla, R.J., Gómez, C.M., Kondolf, G.M. 2004. Reservoir-induced hydrological changes in the Ebro river basin (NE Spain). Journal of Hydrology 290, 117-136. https://doi.org/10.1016/j.jhydrol.2003.12.002

Batica, J., Gourbesville, P. 2016. Resilience in flood risk management: a new communication tool. Procedia Engineering 154, 811-817. https://doi.org/10.1016/j.proeng.2016.07.411

Beguería, S., López-Moreno, J.I., Lorente, A., Seeger, M., García-Ruiz, J.M. 2003. Assessing the effect of climate oscillations and land-use changes on streamflow in the Central Spanish Pyrenees. Ambio 32 (4), 283-286. https://doi.org/10.1579/0044-7447-32.4.283

Cabezas, A., Comín, F.A., Beguería, S., Trabucchi, M. 2009. Hydrologic and landscape changes in the Middle Ebro River (NE Spain): implications for restoration and management. Hydrology and Earth System Sciences 13, 1-12. https://doi.org/10.5194/hess-13-273-2009

Constante, A., Peña, J.L., Muñoz, A., Picazo, J. 2010. Climate and anthropogenic factors affecting alluvial fan development during the late Holocene in the central Ebro Valley, northeast Spain. The Holocene 21 (2), 275-286. https://doi.org/10.1177/0959683610378873

De Bruijn, K.M. 2005. Resilience and flood risk management: a systems approach applied to lowland rivers. DUP Science, Delft, $210 \mathrm{pp}$. 
Díaz Redondo, M., Marchamalo, M., Egger, G., Magdaleno, F. 2018. Toward floodplain rejuvenation in the middle Ebro River (Spain): from history to action. Geomorphology 317, 117-127. https://doi.org/10.1016/j.geomorph.2018.05.014

Domenech, S., Ollero, A., Sánchez Fabre, M. 2008. Núcleos de población en riesgo de inundación fluvial en Aragón: diagnóstico y evaluación para la ordenación del territorio. Geographicalia 54, 17-44. https://doi.org/10.26754/ojs_geoph/geoph.2008541095

García-Ruiz, J.M., Lana-Renault, N. 2011. Hydrological and erosive consequences of farmland abandonment in Europe, with special reference to the Mediterranean region. A review. Agriculture, Ecosystems and Environment 140 (3-4), 317-338. https://doi.org/10.1016/j.agee.2011.01.003

García-Ruiz, J. M., López-Moreno, J. I., Vicente-Serrano, S. M., Lasanta T., Beguería, S. 2011. Mediterranean water resources in a global change scenario. Earth Science Reviews 105 (3-4), 121-139. https://doi.org/10.1016/j.earscirev.2011.01.006

García Ruiz, J.M., López Moreno, J.I., Lasanta, T., Vicente, S.M., González Sampériz, P., Valero, B.L., Sanjuán, Y., Beguería, S., Nadal, E., Lana-Renault, N., Gómez Villar, A. 2015. Los efectos geoecológicos del cambio global en el Pirineo central español: una revisión a distintas escalas espaciales y temporales. Pirineos 170, e012. https://doi.org/10.3989/Pirineos.2015.170005

García-Vera, M.A. 2013. The application of hydrological planning as a climate change adaptation tool in the Ebro basin. Water Resources Development 29(2), 219-236. https://doi.org/10.1080/07900627.2012.747128

Gargantilla, D., Calvo, A., Chopo, S., Polanco, L., Moreno, M.L., Pardos, M., San Roman, J., Gómez, R. 2020. Prevención, protección, preparación y reparación: medidas para la disminución del riesgo de inundación en el eje del Ebro. Boletín CIREF 12 (in press).

Guillén, J., Palanques, A. 1997. A historical perspective of the morphological evolution in the lower Ebro river. Environmental Geology 30 (3/4), 174-180. https://doi.org/10.1007/s002540050144

Hillman, M. 2009. Integrating knowledge: the key challenge for a new paradigm in river management. Geography Compass 3 (6), 1988-2010. https://doi.org/10.1111/j.1749-8198.2009.00278.x

Horacio, J., Ollero, A., Noguera, I., Fernández Pasquier, V. 2019. Flooding, channel dynamics and transverse infrastructure: a challenge for Middle Ebro river management. Journal of Maps 15 (2), 310-319. https://doi.org/10.1080/17445647.2019.1592719

Klijn, F., Kreibich, H., De Moel, H., Penning-Rowsell, E. 2015. Adaptive flood risk management planning based on a comprehensive flood risk conceptualisation. Mitigation and Adaptation Strategies for Global Change 20 (6), 845-864. https://doi.org10.1007/s11027-015-9638-z

López-Moreno, J.I., Vicente-Serrano, S.M., Moran-Tejeda, E., Zabalza, J., Lorenzo-Lacruz, J., García-Ruiz, J.M. 2011. Impact of climate evolution and land use changes on water yield in the Ebro basin. Hydrology and Earth System Science 15, 311-322. https://doi.org/10.5194/hess-15-311-2011

López-Moreno, J.I., Vicente-Serrano, S.M., Revuelto, J., Gilaberte, M., Azorín-Molina, C., Morán-Tejeda, E., García-Ruiz, J.M., Tague, C. 2014. Respuesta hidrológica del Pirineo central al cambio ambiental proyectado para el siglo XXI. Pirineos, Revista de Ecología de Montaña 169. https://doi.org/10.3989/Pirineos.2014.169004

Lorenzo-Lacruz, J., Vicente-Serrano, S.M., López-Moreno, J.I., Morán-Tejeda, E., Zabalza, J. 2012. Recent trends in Iberian streamflows (1945-2005). Journal of Hydrology 414-415, 463-475. https://doi.org/10.1016/j.jhydrol.2011.11.023

Magdaleno, F. 2011. Evolución hidrogeomorfológica del sector central del río Ebro a lo largo del siglo XX. Implicaciones ecológicas para su restauración. Tesis doctoral, Universidad Politécnica de Madrid.

Maldonado, A. 1972. El Delta del Ebro. Estudio sedimentológico y estratigráfico. Boletín de Estratigrafía, 1, Universidad de Barcelona, $486 \mathrm{p}$.

Martín Vide, J.P. (Coord.). 2018. Estudio del equilibrio sedimentario del río Ebro en el tramo urbano de Zaragoza. Informe inédito, Ayuntamiento de Zaragoza.

Najes, L., Ollero, A., Sánchez Fabre, M. 2019. Evolución y dinámica geomorfológica actual del río Ebro en la Reserva Natural Dirigida de los Sotos y Galachos (Zaragoza). Cuaternario y Geomorfología 33 (1-2), 47-63. https://doi.org/10.17735/cyg.v33i1-2.67874 
Ollero, A. 1992. Los meandros libres del río Ebro (Logroño-La Zaida): geomorfología fluvial, ecogeografía y riesgos. Tesis doctoral, Universidad de Zaragoza.

Ollero, A. 2010. Channel changes and floodplain management in the meandering middle Ebro River, Spain. Geomorphology 117, 247-260. https://doi.org/10.1016/j.geomorph.2009.01.015

Ollero, A. 2011. Los cauces fluviales como indicadores de cambio global: propuesta metodológica. Zubía monográfico 23, 187-200.

Ollero, A., Ibisate, A., Granado, D., Real de Asua, R. 2015. Channel responses to global change and local impacts: perspectives and tools for floodplain management (Ebro River and tributaries, NE Spain). In: P.F. Hudson, H. Middelkoop (Eds.), Geomorphic Approaches to Integrated Floodplain Management of Lowland Fluvial Systems in North America and Europe. Springer, New York, pp. 27-52.

Ollero, A., Ibisate, A., Acín, V., Ballarín, D., Granado, D., Horacio, J., Mora, D., Nadal, E., Sánchez Fabre, M., Sebastián, M., Segura, F., Valls, A. 2017. Dynamique fluviale, changement global et pression anthropique dans le bassin, le cours et le delta de l'Èbre. Sud-Ouest Européen 44, 41-54. https://doi.org/10.4000/soe.3186

Parsons, M., Thoms, M.C. 2018. From academic to applied: Operationalising resilience in river systems. Geomorphology 305, 242-251. https://doi.org/10.1016/j.geomorph.2017.08.040

Pueyo, Á., Climent, E., Ollero, A., Pellicer, F., Peña, J.L., Sebastián, M. 2018. L’interaction entre Saragosse et ses cours d'eau: évolution, conflits et perspectives. Sud-Ouest Européen, 44, 7-23. https://doi.org/10.4000/soe.3040

Rull, V. 2018. El Antropoceno. Ed. Catarata, CSIC, 141 p.

Sánchez Fabre, M., Ballarín, D., Mora, D., Ollero, A., Serrano Notivoli, R., Saz, M.A. 2015. Las crecidas del Ebro medio en el comienzo del siglo XXI. In: J. De la Riva, P. Ibarra, R. Montorio, M. Rodrigues (Eds.), Análisis espacial y representación geográfica: innovación y aplicación. Universidad de Zaragoza y AGE, Zaragoza, pp. 1853-1862.

Sánchez Fabre, M., Ollero, A., Moreno, M.L., Losada, J.A., Sánchez Puertas, R., Serrano Notivoli, R. 2017. Évolution hydrologique et inondations récentes dans l'Èbre moyen. Sud-Ouest Européen 44, 97-116. https://doi.org/10.4000/soe.3474

Steffen, W., Sanderson, A., Jäger, J., Tyson, P.D., Moore III, B., Matson, P.A., Richardson, K., Oldfield, F., Schellnhuber, H.J., Turner II, B.L., Wasson, R.J. 2004. Global change and the Earth system: a planet under pressure. Springer, Heidelberg.

Stoppani, A. 1873. Corso di Geologia. Volume II: Geologia Stratigrafica. G. Bernardoni e G. Brigola Editori, Milan.

Van Wesenbeeck, B.K., Ijff, S., Jongman, B., Balog, S., Kaupa, S., Bosche, L., Lange, G.M., Holm-Nielsen, N., Nieboer, H., Taishi, Y., Kurukulasuriya, P., Meliane, I. 2017. Medidas de protección contra inundaciones basadas en la naturaleza. Principios y orientaciones para la implementación. Deltares y Banco Mundial, Washington.

Waters, C.N., Zalasiewicz, J., Summerhayes, C., Barnosky, A.D, Poirier, C., Galuszka, A., Cearreta, A., Edgeworth, M., Ellis, E.C., Jeandel, C., Leinfelder, R., McNeill, J.R., Richter, D. de B., Steffen, W., Syvitski, J., Vidas, D., Wagreich, M., Williams, M., Zhisheng, A., Grinevald, J., Odada, E., Oreskes, N., Wolfe, A.P. 2016. The Anthropocene is functionally and stratigraphically distinct from the Holocene. Science 351 (6269). htpps://doi.org/10.1126/science.aad2622

Waylen, K.A., Holstead, K.L., Colley, K., Hopkins, J. 2018. Challenges to enabling and implementing Natural Flood Management in Scotland. Journal of Flood Risk Management 11, 1078-1089. https://doi.org/10.1111/jfr3.12301

Woodward, M., Kapelan, Z., Gouldby, B. 2014. Adaptive flood risk management under climate change uncertainty using real options and optimization. Risk Analysis 34(1), 75-92. https://doi.org/10.1111/risa.12088

Zalasiewicz, J., Waters, C.N., Summerhayes, C., Wolfe, A.P., Barnosky, A.D., Cearreta, A., Crutzen, P., Ellis, E.C., Fairchild, I.J., Gałuszka, A., Haff, P., Hajdas, I., Head, M.J., Ivar do Sul, J., Jeandel, C., Leinfelder, R., McNeill, J.R., Neal, C., Odada, E., Oreskes, N., Steffen, W., Syvitski, J.P.M., Wagreich, M., Williams, M. 2017. The Working Group on the 'Anthropocene': summary of evidence and recommendations. Anthropocene 19, 55-60. https://doi.org/10.1016/j.ancene.2017.09.001 